\title{
PENGUNGKAPAN ANTI KORUPSI DAN KI NERJ A KEUANGAN PERUSAHAAN: STUDI KASUS PERUSAHAAN TERDAFTAR DI INDEKS SRI KEHATI
}

\author{
Nina Karina Karim \\ Animah \\ Elin Erlina Sasanti
}

\begin{abstract}
Corruption within the corporation has become an important issue in the academic and public debate. The negative consequences caused by companies that engage in corruption are enormous, such as market distortion and incentives, resource allocation inefficiencies, as well as the increased of poverty and social inequality. Companies have the opportunity through a corporate responsibility (CSR) to prevent the problem of corruption. As important as labor, human and environmental rights, corruption mitigation is an important aspect in promoting CSR. CSR can be profitable in sales revenue and market share by improving the perception of ethical corporate customers. However, with the involvement of corruption, it can reduce the confidence of investors and the public against the company which may result in reduced financial performance. The purpose of this study is to determine empirically the correlation of anti-corruption disclosure reported by the companies listed in the Sri Kehati Index and FTSEGoods Bursa Malaysia Index on their financial performance, both the short and long term. The results showed that only the whistle blowing policies were fully disclosed by all companies in the sample of this study. The results also show that the disclosure of anti-corruption has significant influence on the company's profitability only in the long term for companies registered in Sri Kehati Indonesia index. As for the sample of companies registered in Malaysia FTSEGoods Index, the results showed that the disclosure of anti-corruption affect the company's financial performance both in the short term and in the long term. This implies that investors were responding to the anti corruption issues disclosed by the companies and companies should keep the disclosure practice in the future.
\end{abstract}

Keywords: anti-corruption, corporate social responsibility, disclosure, financial performance.

\section{Pendahuluan}

\subsection{Latar Belakang}

Korupsi dalam korporasi telah menjadi isu penting dalam perdebatan akademis dan masyarakat umum. Korupsi adalah penyalahgunaan kekuasaan publik atau sumber daya organisasi untuk kepentingan pribadi atau personal, dan umumnya dipahami sebagai suatu tindakan yang sangat tidak diinginkan untuk masyarakat (Doh, Rodriguez, Uhlenbruck, Collins \& Eden, 2003; Lange, 2008). Akibat negatif yang disebabkan oleh perusahaan yang melakukan korupsi sangatlah besar, seperti distorsi pasar dan insentif, alokasi sumber daya yang tidak efisien, serta meningkatkan kemiskinan dan ketimpangan sosial (O'Higgins, 2006; Osuji, 2011). Sementara itu perusahaan di seluruh dunia dituntut untuk semakin bertanggung jawab untuk terlibat dalam memberikan kontribusi positif terhadap masyarakat di mana mereka tinggal. Para peneliti telah mengamati bahwa terdapat korelasi antara CSR dan kinerja 
keuangan perusahaan. CSR dapat menguntungkan pendapatan penjualan dan pangsa pasar dengan meningkatkan persepsi etis pelanggan perusahaan. Namun dengan adanya korupsi, semua itu dapat mengurangi kepercayaan investor dan publik terhadap perusahaan yang dapat berakibat pada menurunnya kinerja keuangan perusahaan.

Perusahaan memiliki peluang melalui tanggung jawab perusahaan (CSR) untuk tidak hanya mencegah masalah korupsi, tetapi juga manfaat dari ketiaadaan korupsi (Hills et al., 2009). Pengungkapan korupsi dapat membantu untuk memberikan akuntabilitas dengan meningkatkan kesadaran masyarakat dan memaksa perusahaan lain yang sejenis untuk mengadopsi prinsip-prinsip anti-korupsi. Melaporkan program anti-korupsi memberikan tanda bahwa perusahaan bertanggung jawab atas perilaku karyawan mereka dan bahwa mereka mengakui konsekuensi negatif yang dapat mempengaruhi reputasi, integritas dan legitimasi mereka jika mereka terlibat dalam korupsi (ACCA, 2008). Strategi pencegahan korupsi dapat dimasukkan dalam praktek tanggung jawab sosial perusahaan dan dikomunikasikan kepada semua pihak dalam perusahaan serta pemangku kepentingan baik internal maupun eksternal (Hills et al, 2009).

Pada awalnya penelitian tentang pengungkapan CSR lebih berfokus pada isu yang berkaitan dengan lingkungan. Setelah tahun 1999, penelitian mengenai pengungkapan CSR mulai mengangkat isu sosial, lingkungan dan ekonomi (KPMG, 2008). Sejak itu, komponen lain dari CSR mulai mendapatkan perhatian walaupun sebagian besar hanya menunjukkan isu-isu sosial dan lingkungan secara umum (Gunawan, 2007). Weyzig (2009) menyatakan bahwa pada dasarnya, inisiatif CSR harus berkaitan dengan isuisu tertentu, seperti korupsi. Transparency International (2009a) berpendapat bahwa pengungkapan anti-korupsi merupakan indikator kuat dari kualitas dan kelengkapan upaya perusahaan dalam menangani korupsi. Namun, penelitian tentang CSR, terutama pada isu tertentu seperti korupsi masih sangat terbatas (Dissanayake et al, 2011; Hoi dan Lin, 2012; Joseph et al, 2015). Dissanayake et al. (2011) menemukan bahwa pengungkapan tentang pemberantasan penyuapan cenderung meningkat dengan adanya pemberitaan negatif dari media serta pergerakan International Government Organisation dalam memerangi suap di perusahaan global. Sementara Hoi dan Lin (2012) menemukan bahwa CSR dapat mencegah dan mengontrol korupsi perusahaan dalam dua cara yaitu peraturan ekstrinsik yang menekankan pengawasan dan hukuman serta motivasi intrinsik yang menekankan integritas dan self-monitoring. Hoi dan Lin (2012) juga menyimpulkan bahwa efektivitas pencegahan korupsi sangat didasarkan pada sejauh mana perusahaan berkomitmen untuk bertanggung jawab sosial. Penelitian Joseph et al (2015) mengindikasikan bahwa pengungkapan praktik anti-korupsi di Indonesia dan Malaysia masih dalam tahap yang sangat dini. Joseph et al (2015) juga menunjukkan bahwa pengungkapan prinsip antikorupsi dan praktek whistle-blowing merupakan item yang paling sering dilaporkan dalam laporan tahunan perusahaan. Dalam hubungannya dengan kinerja keuangan perusahaan, Healy dan Serafeim (2011) menemukan bahwa pengungkapan usaha memerangi korupsi berhubungan dengan kinerja keuangan perusahaan.

Indeks Persepsi Korupsi (CPI) yang diterbitkan oleh Transparency International (2014) mengungkapkan bahwa Malaysia adalah negara yang dianggap lebih baik dalam hal membatasi korupsi bila dibandingkan dengan Indonesia dan negara ASEAN lainnya, seperti Thailand, Filipina, dan Vietnam. 
Malaysia dan Indonesia adalah negara yang sangat diatur, memiliki hukum yang serupa dan aturan yang dibentuk oleh masing-masing pemerintah untuk membatasi korupsi. Malaysia dan Indonesia adalah dua negara besar di Asia Tenggara, yang dianggap sebagai negara terkemuka dalam hal penduduk dan sumber daya alam (National Geographic, 2015). Faktor-faktor ini dapat menarik investor asing sebagai peluang besar untuk bisnis. Namun, sebuah studi yang dilakukan oleh Political \& Economic Risk Consultancy Ltd (2011) melaporkan bahwa baik Indonesia dan Malaysia menghadapi masalah korupsi yang dapat mengurangi kepercayaan investor untuk melakukan bisnis di kedua negara ini. Sejak 8 Juni 2009, Yayasan KEHATI bekerjasama dengan PT Bursa Efek Indonesia (BEI) meluncurkan indeks SRI KEHATI yang mengacu pada tata cara Sustainable and Responsible Investment (SRI) dengan nama Indeks SRI KEHATI. Tujuan dibentuknya indeks ini adalah untuk memberikan informasi secara terbuka kepada masyarakat luas mengenai ciri dari perusahaan terpilih pada indeks SRI KEHATI yang dianggap memiliki bermacam bentuk pertimbangan dalam usahanya berkaitan dengan kepedulian pada lingkungan, tata kelola perusahaan, keterlibatan masyarakat, sumber daya manusia, hak asasi manusia, dan perilaku bisnis dengan etika bisnis yang diterima di tingkat international. Demikian juga dengan Bursa Malaysia telah meluncurkan indeks FTSEGood Bursa Malaysia Index untuk perusahaan yang berkaitan dengan kepedulian pada lingkungan, sosial dan tata kelola perusahaan sejak Desember 2014. Masing-masing indeks yang terdaftar dalam bursa pasar modal di Indonesia dan Malaysia tentunya memiliki keunikan khusus dalam hal menghadapi kepentingan sosial dan isuisu berdasarkan lingkungan internal dan eksternal, termasuk anti korupsi sehingga imbal balik keuangan berupa keuntungan yang diperoleh perusahaan tertentu dapat berbeda untuk masing-masing indeks tersebut. Konsekuensinya, diperlukan telaah lebih lanjut untuk melihat apakah pengungkapan aktivitas anti korupsi perusahaan sebagai bagian dari pengungkapan CSR dapat mempengaruhi kinerja keuangan perusahaan. Pentingnya isu anti korupsi serta masih terbatasnya penelitian empiris mengenai CSR yang khusus menguji hubungan antara pengungkapan anti korupsi dengan kinerja keuangan perusahaan terutama di Indonesia dan Malaysia menyebabkan ruang kosong (research gap) yang akan dimanfaatkan untuk melakukan penelitian ini.

\subsection{Rumusan Masalah}

Berdasarkan uraian tersebut, permasalahan yang akan dibahas pada penelitian ini adalah bagaimana pengungkapan anti korupsi yang dilaporkan oleh perusahaan yang termasuk dalam Indeks Sri Kehati dan FTSEGoods Bursa Malaysia Index dalam laporan tanggung jawab sosial perusahaan maupun laporan tahunan berpengaruh terhadap kinerja keuangan perusahaan yang terdaftar dalam kedua indeks tersebut baik dalam jangka pendek maupun jangka panjang.

\subsection{Tujuan Penelitian}

Studi literatur terdahulu telah menggunakan berbagai macam teori untuk menjelaskan tanggung jawab sosial yang dilakukan perusahaan, seperti Teori Keagenan (Haniffa dan Cooke 2002; Akhtaruddin et al, 2009), Teori Pemangku Kepentingan (Ullman, 1985; Roberts 1992) dan Teori Legitimasi (Islam \& Deegan 2008, 2010). Chen dan Roberts (2010) menunjukkan bahwa teori legitimasi dan pemangku kepentingan merupakan teori yang dianggap 
paling berpengaruh dalam menjelaskan tanggung jawab sosial perusahaan. Kedua teori ini didasarkan pada 'kerangka ekonomi politik,' yang menyediakan fondasi untuk sistem berbasis teori (Gray et al. 1996) karena keduanya berkonsentrasi pada interaksi organisasi dan masyarakat (Gray et al. 1995). Namun, kedua teori ini berbeda dalam pendekatan mereka terhadap menyelidiki fenomena sosial (Chen \& Roberts, 2010). Teori stakeholder berpendapat bahwa alasan di balik tanggung jawab sosial perusahaan adalah berdasarkan kebutuhan informasi stakeholders, sedangkan teori legitimasi dianggap mendorong tanggung jawab sosial perusahaan berdasarkan pada keinginan perusahaan mempertahankan legitimasinya dengan masyarakat (Deegan, 2011). Teori kerangka ekonomi politik menunjukkan bahwa perusahaan beroperasi dalam kerangka sosial, politik dan ekonomi. Perusahaan mempengaruhi masyarakat, dan pada gilirannya dipengaruhi oleh masyarakat di mana mereka beroperasi (Islam \& Deegan 2008; Deegan 2009). Perusahaan mungkin terlibat dalam kegiatan sosial dan lingkungan dan sukarela melaporkan kegiatan tersebut untuk menanggapi tekanan dari masyarakat.

Teori legitimasi berpendapat bahwa organisasi selalu berusaha untuk meyakinkan bahwa kegiatan yang mereka lakukan berada pada lingkup dan norma yang bisa diterima oleh lingkungan sosial tempat mereka beroperasi. Teori ini didasari oleh anggapan bahwa terdapat kontrak sosial antara organisasi dan lingkungan sosial yang menuntut agar organisasi melaporkan kegiatan mereka secara sukarela bila pihak manajemen memandang bahwa kegiatan tersebut diharapkan oleh masyarakat (Guthrie et al., 2004). Dari sudut pandang teori legitimasi, pengungkapan informasi digunakan sebagai alat bagi organisasi untuk mencitrakan dirinya sebagai organisasi yang penuh tanggung jawab dan beroperasi sesuai dengan nilai-nilai sosial agar dapat mempertahankan atau memperoleh legitimasi sosial (Cuganesan, Ward \& Guthrie, 2007). Legitimasi dianggap penting bagi perusahaan karena legitimasi masyarakat terhadap perusahaan merupakan faktor yang strategis bagi perkembangan perusahaan di masa depan. Untuk itu sebagai suatu sistem yang mengutamakan masyarakat, aktivitas operasional perusahaan juga harus sesuai dengan harapan masyarakat karena kelangsungan hidup dan perumbuhan perusahaan bergantung pada bagaimana perusahaan secara terus menerus berevolusi dan beradaptasi dengan perubahan tuntutan masyarakat (Walden \& Schwartz, 1997).

Perusahaan yang termasuk dalam indeks Sri Kehati Bursa Efek Indonesia dan FTSE4 Good Bursa Malaysia merupakan perusahaanperusahaan yang dianggap memiliki bermacam bentuk pertimbangan dalam usahanya berkaitan dengan kepedulian pada lingkungan, tata kelola perusahaan, keterlibatan masyarakat, sumber daya manusia, hak asasi manusia, dan perilaku bisnis serta etika bisnis yang diterima di tingkat internasional. Untuk mempertahankan posisi mereka dalam indeks tersebut, perusahaan akan cenderung melakukan aktivitas CSR untuk menciptakan dan menjaga citra positif untuk mempengaruhi nilai perusahaan (Kang et al., 2010). Hal ini karena melalui aktivitas CSR tersebut perusahaan mencitrakan dirinya kepada masyarakat sebagai organisasi yang penuh tanggung jawab dan beroperasi sesuai dengan nilai-nilai sosial sehingga dapat meningkatkan reputasi mereka serta dapat meraih kepercayaan investor yang pada akhirnya mampu mempengaruhi kinerja keuangan perusahaan. 
Nina Karina K., Animah, \& Elin Erlina S., : Pengungkapan Anti Korupsi ...

\section{Tinjauan Pustaka}

\subsection{Pengungkapan Anti Korupsi}

Indeks Persepsi Korupsi (CPI) yang diterbitkan oleh Transparency International (2014) mengungkapkan bahwa Malaysia dipersepsikan sebagai Negara yang lebih baik dalam hal tingkat korupsi dibandingkan dengan Indonesia dan negara ASEAN lainnya, seperti Thailand, Filipina, dan Vietnam. Beberapa upaya telah diperkenalkan dan dilaksanakan oleh pemerintah Malaysia yang bertujuan untuk memerangi korupsi dan mempromosikan integritas dalam masyarakat sebagai bagian dari inisiatif reformasi. Indonesia berada di peringkat pada Indeks Persepsi Korupsi di 107 yang sangat jauh di bawah negara-negara sekitar lainnya, seperti Singapura, Filipina, dan Thailand (Transparency International 2014). Untuk mengurangi tingkat korupsi, pemerintah telah membuat berbagai upaya untuk memperbaiki situasi ini dengan mengembangkan banyak peraturan.

Perusahaan didorong untuk menerapkan strategi untuk memerangi kegiatan korupsi (Hills et al., 2009). Oleh karena itu, strategi pencegahan korupsi dapat dimasukkan sebagai bagian dari praktek tanggung jawab sosial perusahaan dan dikomunikasikan kepada semua bagian perusahaan. Selain itu semua inisiatif CSR yang membahas upaya korupsi harus dikomunikasikan kepada pemangku kepentingan internal dan eksternal. Hal ini sejalan dengan Transparency Internasional (2010), yang menunjukkan bahwa penilaian dan mitigasi risiko perusahaan akan praktik suap dan korupsi harus menjadi bagian dari pendekatan perusahaan dalam melaksanakan tanggung jawab sosialnya. Dorongan untuk pengintegrasian tanggung jawab perusahaan dan inisiatif anti-korupsi juga telah dilakukan oleh UN Global Compact dan komunitas investasi internasional (Transparency International, 2010). Sangatlah penting bagi organisasi untuk mengkomunikasikan praktek anti korupsi mereka ke semua anggota organisasi (Coonjohn dan Lodin, 2011).

Pengungkapan korupsi membantu perusahaan mencapai tujuan organisasi baik secara internal maupun eksternal (Hess, 2009). Bierstaker (2009) merekomendasikan bahwa Direksi harus menyetujui kebijakan antikorupsi dalam pedoman kegiatan CSR. Dianjurkan bahwa harus ada mekanisme untuk mencegah perilaku yang tidak etis seperti korupsi, dalam pelaksanaan praktik CSR di perusahan. Pengungkapan korupsi dapat membantu untuk memberikan akuntabilitas dengan meningkatkan kesadaran masyarakat dan memaksa perusahaan lain yang sejenis untuk mengadopsi prinsip-prinsip anti-korupsi. Pengungkapan anti-korupsi adalah cara untuk memastikan bahwa manajer harus bertanggung jawab kepada publik. Melaporkan program anti-korupsi memberikan tanda bahwa perusahaan bertanggung jawab atas perilaku karyawan mereka dan bahwa mereka mengakui konsekuensi negatif yang dapat mempengaruhi reputasi, integritas dan legitimasi mereka jika mereka terlibat dalam korupsi (ACCA, 2008).

Penilaian kinerja keuangan merupakan salah satu cara yang dilakukan oleh pihak manajemen agar dapat memenuhi kewajibannya kepada para pemilik perusahaan. Kinerja keuangan diartikan sebagai penentuan ukuranukuran tertentu yang dapat mengukur keberhasilan suatu perusahaan dalam menghasilkan laba. Kinerja keuangan perusahaan merupakan suatu gambaran mengenai kondisi dan keadaan dari suatu perusahaan yang dianalisis dengan alat-alat analisis keuangan, sehingga dapat diketahui baik atau buruknya kondisi keuangan dan prestasi kerja sebuah perusahaan dalam waktu tertentu. 
Pada umumnya ukuran kinerja keuangan dapat diukur berdasarkan basis akuntansi dan basis pasar untuk mencerminkan dua dimensi dari kinerja keuangan perusahaaan, yaitu keuntungan jangka pendek dan evaluasi pasar atas profitabilitas perusahaan di masa depan (Luo \& Bhattacharya, 2006). Ukuran kinerja berbasis akuntansi seperti Return on Asset (ROA), merepresentasikan profitabilitas perusahaan dalam jangka pendek atau efisiensi manajemen perusahaan, dan memberikan informasi langsung tentang bagaimana alokasi sumber daya tertentu dapat menciptakan keuntungan bagi perusahaan pada periode tersebut (Cochran \& Wood, 1984; Hull \& Rothenberg, 2008). Sebaliknya, ukuran kinerja berbasis pasar, seperti nilai Tobin's $Q$, mengungkapkan bagaimana investor mengevaluasi kemampuan perusahaan untuk menciptakan keuntungan di masa depan (Luo \& Bhattacharya, 2006).

\subsection{Kerangka Konseptual Penelitian}

Korelasi antara pengungkapan anti korupsi dalam CSR dan kinerja keuangan perusahaan digambarkan pada gambar berikut ini.

Gambar 2.1. Kerangka Konseptual Penelitian

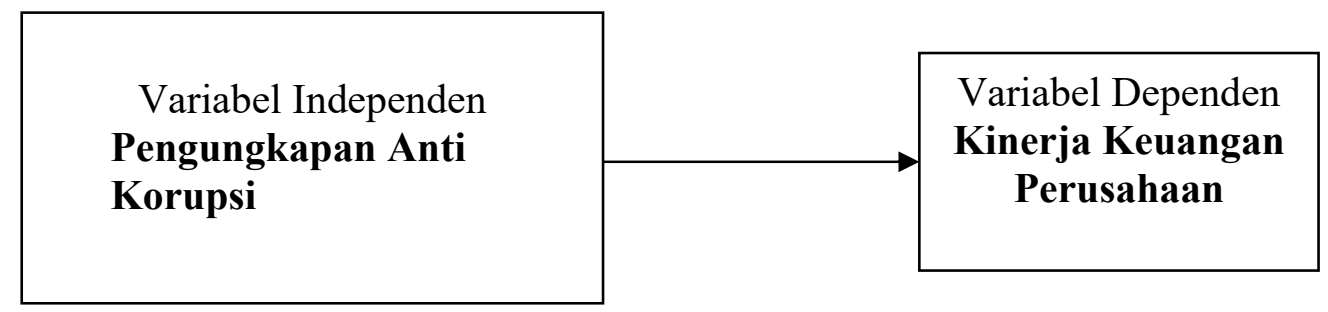




\subsection{Hipotesis Penelitian \\ 2.3.1. Pengaruh pengungkapan anti korupsi terhadap kinerja keuangan perusahaan}

Sebagai salah satu bentuk tanggung jawab perusahaan terhadap masyarakat dan para stakeholders lainnya, perusahaan seringkali terlibat dalam kegiatan-kegiatan CSR. Melalui kegiatan CSR tersebut, para stakeholders dapat memberikan apresiasi yang lebih bagi perusahaanperusahaan yang terlibat dalam kegiatan CSR. Namun, investor tidak akan menghargai kontribusi positif kegiatan tanggung jawab sosial perusahaan dan kontribusi perusahaan yang tidak dipublikasikan oleh perusahaan kecuali mereka memiliki dampak pada reputasi perusahaan (Van Dijken, 2007). Dengan demikian, pengungkapan kegiatan CSR diperlukan karena berdasarkan fakta bahwa perusahaan memiliki kewajiban kepada masyarakat atau memiliki kontrak sosial dengan masyarakat. Dari sudut pandang teori legitimasi, pengungkapan informasi digunakan sebagai alat bagi organisasi untuk mencitrakan dirinya sebagai organisasi yang penuh tanggung jawab dan beroperasi sesuai dengan nilai-nilai sosial agar dapat mempertahankan atau memperoleh legitimasi sosial (Cuganesan, Ward \& Guthrie, 2007). Legitimasi dianggap penting bagi perusahaan karena legitimasi masyarakat terhadap perusahaan merupakan faktor yang strategis bagi perkembangan perusahaan di masa depan. Pengungkapan menyediakan kesempatan bagi perusahaan untuk menyebarkan informasi berharga terutama untuk para pemangku kepentingan seperti analis saham, pasar modal dan investor. Melalui pelaporan CSR tersebut, investor akan mengevaluasi strategi, arus kas dan reputasi perusahaan.

Pengungkapan aktivitas perusahaan yang berkaitan dengan CSR merupakan salah satu cara untuk mengirimkan sinyal positif kepada stakeholders dan pasar mengenai prospek perusahaan di masa yang akan datang bahwa perusahaan memberikan jaminan atas keberlangsungan hidup perusahaan dimasa yang akan datang. Pengungkapan CSR dapat mengirimkan sinyal promosi atau informasi lain yang menyatakan bahwa perusahaan tersebut lebih baik daripada perusahaan lain karena peduli dengan dampak ekonomi, lingkungan dan sosial dari aktivitas perusahaan. Untuk itu sebagai suatu sistem yang mengutamakan masyarakat, aktivitas operasional perusahaan juga harus sesuai dengan harapan masyarakat karena kelangsungan hidup dan perumbuhan perusahaan bergantung pada bagaimana perusahaan secara terus menerus berevolusi dan beradaptasi dengan perubahan tuntutan masyarakat (Walden \& Schwartz, 1997). Semakin luas pengungkapan yang disampaikan kepada investor serta masyarakat sebagai pemangku kepentingan perusahaan maka akan menimbulkan kepercayaan mereka kepada perusahaan. Kepercayaan kepada perusahaan ditunjukkan melalui diterimanya produk-produk perusahaan sehingga akan meningkatkan kinerja keuangan perusahaan.

Pengungkapan anti korupsi sebagai bagian dari pengungkapan CSR dengan sendirinya juga mengirimkan sinyal yang menyatakan bahwa perusahaan peduli dengan pencegahan korupsi yang dapat mengancam keberlangsungan hidup perusahaan dan msyarakat pada umumnya. Walaupun penelitian terdahulu lebih banyak mengungkapkan pengaruh pengungkapan CSR terhadap kinerja keuangan (Heal dan Gareth, 2004; Dahlia dan Siregar, 2008), Healy dan Serafeim (2011) mengindikasikan bahwa pengungkapan anti korupsi juga berkorelasi dengan kinerja keuangan 
perusahaan. Berdasarkan uraian tersebut, maka dapat dirumuskan hipotesis sebagai berikut. berikut:

Berdasarkan uraian tersebut maka diajukan hipotesis penelitian sebagai

H1: Pengungkapan anti korupsi oleh perusahaan akan berpengaruh positif terhadap kinerja keuangan perusahaan baik dalam jangka pendek maupun jangka panjang.

\section{Metode Penelitian}

\subsection{Jenis/ Rancangan Penelitian}

Penelitian ini dirancang untuk menguji korelasi pengungkapan anti korupsi terhadap kinerja keuangan perusahaan yang terdaftar di indeksi Sri Kehati Bursa Efek Indonesia dan indeks FTSE4Good Bursa Malaysia tahun 2014-2015. Penelitian ini merupakan penelitian kuantitatif karena menekankan pada pengujian teori-teori sebelumnya dengan pengujian menggunakan prosedur statistik. (Indriantoro, 2002; 12). Berdasarkan karakteristik permasalahan, penelitian ini diklasifikasikan sebagai penelitian kausalitas karena bertujuan menjelaskan pengaruh atau hubungan (kausal) antar variabel. (Solimun, 2007). Pengaruh antar variabel tersebut dirumuskan dalam bentuk hipotesis penelitian yang akan diuji kebenarannya. Pengujian hipotesis ini menjelaskan fenomena dalam bentuk hubungan antar variabel yang merupakan hubungan kausalitas antar beberapa variabel eksogen yang mempengaruhi variabel endogen.

\subsection{Populasi, Sampel dan Teknik Pengambilan Sampel}

Sesuai dengan yang dinyatakan dalam permasalahan, penelitian ini dibatasi pada hubungan antara pengungkapan anti korupsi terhadap kinerja keuangan perusahaan yang terdaftar di indeksi Sri Kehati Bursa Efek Indonesia dan indeks FTSE4Good Bursa Malaysia tahun 2014-2015. Perusahaan yang akan dijadikan obyek penelitian adalah perusahaan yang terdaftar pada indeksi Sri Kehati Bursa Efek Indonesia dan indeks FTSE4Good Bursa Malaysia tahun 2014-2015 yang melaporkan pelaksanaan CSR-nya dalam laporan yang dipublikasi melalui internet untuk tahun 2014-2015. Berdasarkan kriteria tersebut diperoleh 25 perusahaan yang terdaftar pada indeks Sri Kehati dan 34 perusahaan yang terdaftar pada indeks FTSE4Good sebagai populasi dalam penelitian ini. Pemilihan sampel akan dilakukan dengan metode judgment sampling di mana sampel dipilih berdasarkan penilaian terhadap beberapa karakteristik anggota sampel yang disesuaikan dengan tujuan penelitian.

\subsection{Jenis dan Sumber Data}

Data yang digunakan dalam penelitian ini adalah data sekunder yang didapat dari data yang dipublikasikan oleh Bursa Efek Indonesia yang diperoleh dari Indonesian Capital Market Directory 2014-2015 serta laporan tanggung jawab sosial perusahaan (CSR Report), laporan keberlanjutan (Sustainability Report) maupun laporan tahunan (Annual Report) yang dipublikasikan melalui internet untuk tahun 2014-2015 dari masing-masing situs perusahaan atau melalui situs idx.co.id maupun bursamalaysia.com.

\subsection{Variabel Penelitian \\ 3.4.1. I dentifikasi dan Klasifikasi Variabel}


Variabel memberikan gambaran yang lebih nyata fenomene-fenomena yang digeneralisasi dalam konstruk. Maka variabel-variabel dalam penelitian ini dikelompokkan :

1. Variabel dependen yaitu kinerja keuangan perusahaan.

2. Variabel independen yaitu pengungkapan anti korupsi.

\subsubsection{Definisi Operasional Variabel}

\subsubsection{Variabel Dependen}

Variabel dependen yang digunakan pada penelitian ini adalah kinerja keuangan perusahaan. Dua ukuran yang berbeda akan digunakan untuk melihat dua dimensi kinerja keuangan perusahaan. Ukuran yang pertama berdasarkan pada ukuran akuntansi yaitu ROA yang digunakan untuk melihat efisiensi suatu perusahaan dalam menggunakan asetnya selama satu periode akuntansi berjalan serta mencerminkan profitabilitas perusahaan dalam jangka pendek. Penggunaan ROA konsisten dengan penelitian terdahulu yang melihat hubungan antara aktivitas CSR dan kinerja keuangan (Berman et al., 1999; Hull \& Rothenberg, 2008; Kang et al., 2010; Inoue \& Lee, 2011). ROA dihitung dengan formula sbb:

$$
\mathrm{ROA}=\frac{\text { Laba Usaha }}{\text { Total Aset }}
$$

Ukuran yang kedua adalah nilai Tobin's Q yang merupakan ukuran kinerja berbasis pasar. Nilai Tobin's Q mengungkapkan bagaimana investor mengevaluasi kemampuan perusahaan untuk menciptakan keuntungan di masa depan (Luo \& Bhattacharya, 2006). Tobin's Q dihitung dengan formula hasil modifikasi versi Chung dan Pruitt (1994) yan telah digunakan secara konsisten. Modifikasi versi ini secara statistic kira-kira mendekati Tobin's Q asli dan menghasilkan perkiraan $99.6 \%$ dari formula asli yang digunakan oleh Lindenberg dan Ross (1981). Tobin's Q dihitung dengan formula sbb:

Tobin's Q = (Nilai pasar ekuitas + Nilai likuidasi saHam preferen/Total Aset

\subsubsection{Variabel I ndependen}

Yang menjadi variabel independen pada penelitian ini adalah tingkat pengungkapan anti korupsi yang akan diukur dengan menggunakan analisis konten atas informasi yang berhubungan dengan anti korupsi yang diungkapkan dalam laporan tahunan atau laporan tanggung jawab sosial perusahaan maupun laporan keberlangsungan (sustainability report). Item pengungkapan anti korupsi akan dinilai berdasarkan indeks yang diadopsi dari penelitian Dissanayake et al. (2011). Indeks yang digunakan Dissananyake et al. (2011) diadopsi karena indeks ini disusun secara komprehensif melalui analisis yang mendetil atas beberapa pedoman anti korupsi dari International Governmental Organization seperti Persatuan Bangsa Bangsa (PBB), Bank Dunia (World Bank), Transparency International dan Forum Ekonomi Dunia (World Economy Forum). Indeks anti korupsi ini dapat dilihat pada Lampiran 1 terdiri dari 7 tema umum dengan 40 sub kategori. \& tema umum tersebut adalah 1) akuntansi untuk melawan korupsi/suap 2) tanggung jawab dewan dan manajemen senior 3) pembinaan sumber daya manusia untuk melawan korupsi/suap 4) hubungan bisnis yang bertanggungjawab 5) verifikasi pihak eksternal dan jaminan 6) kode etik 7) kebijakan whistle blowing. Setiap pengungkapan akan diberikan nilai satu dan kemudian dijumlahkan untuk mendapatkan skor keseluruhan pengungkapan tiap perusahaan untuk 
kemudian dibagi dengan jumlah total item yang seharusnya diungkapkan. Rumus perhitungan pengungkapan anti korupsi ini dapat dihitung sebagai berikut:

$$
A C D I j=\frac{\sum x i j}{n j}
$$

Di mana:

ACDI = Indeks pengungkapan anti korupsi perusahaan $\mathrm{j}$

$\mathrm{Xij}=1$ jika item diungkapkan, 0 jika tiak diungkapkan

$\mathrm{Nj} \quad=$ Jumlah total pengungkapan anti korupsi $=40$ item

\subsubsection{Variabel Kontrol}

Penelitian ini menggunakan variabel kontrol yaitu ukuran perusahaan dan leverage. Ukuran perusahaan dimasukkan ke dalam persamaan regresi karena ukuran perusahaan diduga memiliki pengaruh signifikan dalam hubungan antara pengungkapan anti korupsi dan kinerja keuangan perusahaan. Perusahaan besar akan lebih luas mengungkapkan anti korupsi dibandingkan dengan perusahaan kecil (Hillman \& Keim, Luo \& Bhattacharya, 2006). Formula yang digunakan untuk mencari nilai ukuran perusahaan adalah:

$$
\text { Ukuran perusahaan }=\text { LnTotal Aset }
$$

Leverage diikutkan sebagai variabel kontrol dalam penelitian ini karena bila dibandingkan dengan perusahaan yang memiliki tingkat leverage rendah, perusahaan yang memiliki tingkat leverage tinggi biasanya akan berbeda dan lebih berhati-hati dalam melakukan investasi pada aktivitas CSR (McWilliams \& Siegel, 2000). Leverage dirumuskan sebagai berikut:

$$
\text { Leverage }=\frac{\text { Total Liabilitas }}{\text { Total Ekuitas }}
$$

\subsection{Model Penelitian}

Penelitian ini menggunakan variabel kinerja keuangan sebagai variabel dependen yang dicerminkan oleh nilai ROA dan Tobin's Q. Sedangkan variabel independen yang digunakan adalah pengungkapan anti korupsi. Model yang akan digunakan untuk menguji hipotesis dalam penelitian ini adalah regresi linier berganda (Multiple Regression Analysis). Terdapat dua model yang akan diajukan yaitu model untuk mengukur kinerja keuangan berbasis akuntansi dengan menggunakan ROA dan model untuk mengukur kinerja keuangan berbasis pasar dengna menggunakan Tobin's Q. Model yang diajukan tersebut adalah:

$$
\begin{aligned}
& \mathrm{ROA}_{j t}=b_{0}+b_{1} A_{C C D I}+b_{2} S_{j t} E_{j t}+b_{3} L E V_{j t}+\varepsilon_{j t} \\
& \operatorname{TOBIN}_{j t}=b_{0}+b_{1} A C D A_{j t}+b_{2} S_{Z} E_{j t}+b_{3} L V_{j t}+\varepsilon_{j t}
\end{aligned}
$$

Di mana:

$\mathrm{ROA}_{\mathrm{jt}} \quad=$ Nilai ROA untuk perusahaan $\mathrm{j}$ tahun $\mathrm{t}$.

TOBIN $_{\mathrm{jt}} \quad=$ Nilai Tobin's $\mathrm{Q}$ untuk perusahaan $\mathrm{j}$ tahun $\mathrm{t}$

$\operatorname{ACDI}_{j \mathrm{j}} \quad=$ Skor pengungkapan anti korupsi perusahaan $\mathrm{j}$ tahun $\mathrm{t}$.

$\mathrm{LEV}_{\mathrm{jt}} \quad=$ tingkat leverage perusahaan $\mathrm{j}$ tahun $\mathrm{t}$.

SIZE $_{j \mathrm{t}} \quad=$ ukuran perusahaan $\mathrm{j}$ tahun $\mathrm{t}$.

\section{Hasil Penelitian dan Pembahasan}




\subsection{Gambaran Umum Penelitian}

Penelitian ini dilakukan terhadap 23 perusahaan yang terdaftar dalam indeks SRI KEHATI Bursa Efek Indonesia dan 25 perusahaan yang terdaftar dalam indeks FTSEGoods Malaysia pada tahun 2015. Daftar nama perusahaan yang termasuk dalam sampel dapat dilihat pada Lampiran 2. Masing-masing perusahaan yang dijadikan sampel telah mengungkapkan isu mengenai anti korupsi baik dalam Sustainability Report atau Laporan Keberlanjutan, Laporan CSR maupun Laporan Tahunan periode 2015. Pengungkapan isu anti korupsi dalam penelitian ini diukur dengan jumlah pengungkapan anti korupsi pada laporan keuangan, laporan CSR, laporan keberlanjutan perusahaan, ataupun kode etik perusahaan. Item pengungkapan anti korupsi diadopsi dari penelitian Dissanayake et al. (2011) yang disusun secara komprehensif melalui analisis yang mendetil atas beberapa pedoman anti korupsi dari International Governmental Organization seperti Persatuan Bangsa Bangsa (PBB), Bank Dunia (World Bank), Transparency International dan Forum Ekonomi Dunia (World Economy Forum). Indeks anti korupsi ini terdiri dari 7 tema umum dengan 40 sub kategori. Tema umum tersebut adalah 1) pengungkapan akuntansi untuk melawan korupsi/suap 2) tanggung jawab dewan dan manajemen senior 3) pembinaan sumber daya manusia untuk melawan korupsi/suap 4) hubungan bisnis yang bertanggungjawab 5) verifikasi dan jaminan pihak eksternal 6) kode etik 7) kebijakan whistle blowing. Setiap pengungkapan diberikan nilai satu dan kemudian dijumlahkan untuk mendapatkan skor keseluruhan pengungkapan tiap perusahaan untuk kemudian dibagi dengan jumlah total item yang seharusnya diungkapkan.

Bila ditelaah lebih lanjut, pengungkapan perusahaan mengenai anti korupsi pada perusahaan Indonesia cukup beragam karena ada yang sudah dibuat sesuai dengan standar GRI dengan menyertakan GRI Index Cross Reference untuk membuktikan kesesuaian isi laporan dengan standar yang ditetapkan namun ada juga yang hanya berupa penjelasan terintegrasi pada bagian tata kelola perusahaan. Penjelasan mengenai anti korupsi juga tertuang pada laporan keberlanjutan dan kode etik perusahaan. Namun, tidak semua perusahaan sampel Indonesia menyediakan kode etik pada website perusahaannya. Pada perusahaan Malaysia, hampir sebagian besar pengungkapan anti korupsi dilakukan pada kode etik yang dapat diunduh pada website masing-masing perusahaan. Pengungkapan anti korupsi perusahaan Malaysia juga ditemukan pada laporan keberlanjutan dan pernyataan tata kelola perusahaan. Dengan beragamnya letak pengungkapan mengenai anti korupsi pada sampel penelitian ini baik sampel perusahaan Indonesia maupun sampel perusahaan Malaysia, dapat disimpulkan bahwa luas pengungkapan dan banyaknya informasi mengenai anti korupsi yang dilaporkan menjadi sangat bervariasi.

\subsection{Analisa Deskriptif}

\subsubsection{Pengungkapan Kebijakan Akuntansi Untuk Melawan Korupsi/ Suap}

Tabel 4.1. Pengungkapan Kebijakan Akuntansi untuk Melawan Suap

\begin{tabular}{|c|c|c|c|c|}
\hline $\begin{array}{l}\mathrm{N} \\
\mathrm{O}\end{array}$ & \multirow[t]{2}{*}{ Item Pengungkapan } & \multicolumn{2}{|c|}{$\begin{array}{c}\text { Indonesia } \\
(n=23)\end{array}$} & $\begin{array}{c}\text { Malaysia } \\
(n=25)\end{array}$ \\
\hline & & Total & $\%$ & Total \\
\hline
\end{tabular}


The company prohibits all forms of

1 bribery whether they take place directly or through third parties The company prohibits its employees from soliciting, arranging or accepting bribes

2 intended for the employee's benefit or that of the employee's family, friends, associates or acquaintances.

The company, its employees or agents make clear commitments that they do not have direct or indirect contributions to political parties, organizations or individuals engaged in politics, as a way of obtaining advantages in business transactions The company discloses all its political contributions.

The company ensures that charitable contribution and sponsorship are not used as a subterfuge for bribery The company publicly discloses all

6 its charitable contribution and sponsorship

The company does not make

7 facilitation payments and takes the initiative to identify and eliminate them

The company prohibits the offer or receipt of gifts, hospitality or expenses whenever they could

8 affect or be perceived to affect the outcome of business transactions and are not reasonable and bona fide The company establishes and maintains an effective system of internal control to counter bribery, comprising financial and

9 organizational checks and balances over the enterprise's accounting and record keeping practices and other business processes related to the program

The company subjects the internal control systems, in particular

10 accounting and record keeping practices, to regular review and

$23 \quad 100 \% \quad 23 \quad 92 \%$


Nina Karina K., Animah, \& Elin Erlina S., : Pengungkapan Anti Korupsi ...

design, implementation and

effectiveness

11 Discloses the number of violations

$17 \quad 74 \%$

8

$32 \%$

12 Reports the number of dismissals of

$14 \%$

2

$8 \%$

Sumber: Data diolah

Tabel 4.1. menunjukkan bahwa untuk item pengungkapan nomor 1, semua perusahaan Indonesia maupun Malaysia telah mengungkapkan bahwa perusahaan melarang semua bentuk suap baik secara langsung maupun tidak langsung. Selain item pengungkapan nomor 1, pada Tabel 4.1. juga dapat dilihat bahwa lebih dari setengah perusahaan Indonesia dalam sampel mengungkapkan item nomor $2(87 \%), 3(65 \%), 5(74 \%), 6(100 \%), 8$ $(87 \%), 9(96 \%), 10(96 \%)$, dan $11(74 \%)$. Sedangkan, bagi perusahaan Malaysia, mengungkapkan item nomor $2(100 \%), 3(60 \%), 5(60 \%), 6$ $(92 \%), 7(60 \%), 8(100 \%), 9(100 \%)$, dan 10 (92\%). Dalam hal jumlah pengungkapan secara umum, Indonesia lebih banyak mengungkapkan beberapa item bila dibandingkan dengan Malaysia. Malaysia memiliki nilai lebih tinggi dari Indonesia pada 5 item $(2,7,8,9$, dan 12) sedangkan Indonesia memiliki nilai lebih tinggi pada 6 item $(3,4,5,6,10$, dan 11).

\subsubsection{Pengungkapan Tanggung J awab Dewan dan Manajer Senior}

Tabel 4.2. Pengungkapan Tanggung Jawab Dewan dan Manajemen Senior

\begin{tabular}{|c|c|c|c|c|c|}
\hline \multirow[t]{2}{*}{$\begin{array}{l}\mathrm{N} \\
\mathrm{O}\end{array}$} & \multirow[t]{2}{*}{ Item Pengungkapan } & \multicolumn{2}{|c|}{$\begin{array}{c}\text { Indonesia } \\
(n=23)\end{array}$} & \multicolumn{2}{|c|}{$\begin{array}{c}\text { Malaysia } \\
(n=25)\end{array}$} \\
\hline & & Total & $\%$ & Total & $\%$ \\
\hline 1 & $\begin{array}{l}\text { The board of directors or equivalent } \\
\text { body should commit to an anti- } \\
\text { corruption policy and program based } \\
\text { on business principles and provide } \\
\text { leadership, resources and active } \\
\text { support for the management's } \\
\text { implementation of the program }\end{array}$ & 20 & $87 \%$ & 25 & $100 \%$ \\
\hline 2 & $\begin{array}{l}\text { The company makes compliance with } \\
\text { the program mandatory for directors } \\
\text { and applies appropriate sanctions for } \\
\text { violations of its program }\end{array}$ & 1 & $4 \%$ & 10 & $40 \%$ \\
\hline 3 & $\begin{array}{l}\text { The company establishes feedback } \\
\text { mechanisms and other internal } \\
\text { processes supporting the continuous } \\
\text { improvement of the program }\end{array}$ & 23 & $100 \%$ & 18 & $72 \%$ \\
\hline 4 & $\begin{array}{l}\text { Senior management of the company } \\
\text { monitors the program and periodically } \\
\text { reviews the program's sustainability, } \\
\text { adequacy and effectiveness, and } \\
\text { implements improvements as } \\
\text { appropriate }\end{array}$ & 23 & $100 \%$ & 25 & $100 \%$ \\
\hline
\end{tabular}




\begin{tabular}{|c|c|c|c|c|c|}
\hline \\
\hline 5 & $\begin{array}{l}\text { Senior management should } \\
\text { periodically report the results of the } \\
\text { program review to the audit } \\
\text { committee, board or equivalent body }\end{array}$ & 1 & $4 \%$ & 10 & $40 \%$ \\
\hline 6 & $\begin{array}{l}\text { Management offers dialogue with the } \\
\text { NGOs and public so as to promote its } \\
\text { awareness of and cooperation with } \\
\text { the fight against bribery and extortion }\end{array}$ & 0 & $0 \%$ & 0 & $0 \%$ \\
\hline 7 & $\begin{array}{l}\text { The audit committee, the board or an } \\
\text { equivalent body should make an } \\
\text { independent assessment of the } \\
\text { adequacy of the program and disclose } \\
\text { its findings in the enterprise's annual } \\
\text { report to shareholders }\end{array}$ & 2 & $9 \%$ & 1 & $4 \%$ \\
\hline
\end{tabular}

Sumber: Data diolah

Tabel 4.2. menyajikan pengungkapan tanggung jawab dewan dan manajer senior mengenai komitmen terhadap isu anti korupsi. Pada Tabel 4.2 dapat dilihat bahwa perusahaan Malaysia lebih banyak mengungkapkan item nomor $1(100 \%), 2(40 \%)$, dan $5(40 \%)$ sedangkan perusahaan Indonesia lebih banyak mengungkapkan item nomor 3 (100\%) dan 7 (9\%). Selain itu, tidak ada satu perusahaan pun baik dari Indonesia maupun Malaysia yang mengungkapkan item nomor 6.

\subsubsection{Pengungkapan Pembinaan Sumber Daya Manusia Untuk Melawan Korupsi/ Suap}

Tabel 4.3. menyajikan pengungkapan mengenai pembinaan sumber daya manusia untuk melawan korupsi/suap. Pada Tabel 4.3 dapat dilihat bahwa semua perusahaan baik dari Malaysia maupun Indonesia mengungkapkan item nomor 1 . Selain itu dapat dilihat bahwa perusahaan Malaysia lebih banyak mengungkapkan item nomor $3(40 \%)$ dan $4(8 \%)$ sedangkan perusahaan Indonesia lebih banyak mengungkapkan item nomor 2 (26\%).

Tabel 4.3. Pembinaan Sumber Daya Manusia untuk Melawan Korupsi

\begin{tabular}{|c|c|c|c|c|c|}
\hline \multirow[t]{2}{*}{$\begin{array}{l}\mathrm{N} \\
\mathrm{O}\end{array}$} & \multirow[t]{2}{*}{ Item Pengungkapan } & \multicolumn{2}{|c|}{$\begin{array}{c}\text { Indonesia } \\
(n=23)\end{array}$} & \multicolumn{2}{|c|}{$\begin{array}{c}\text { Malaysia } \\
(n=25)\end{array}$} \\
\hline & & Total & $\%$ & Total & $\%$ \\
\hline 1 & $\begin{array}{l}\text { Human resources practices including } \\
\text { recruitment, promotion, training, } \\
\text { performance evaluation, } \\
\text { remuneration and recognition should } \\
\text { reflect the companies' commitment } \\
\text { to the program }\end{array}$ & 23 & $100 \%$ & 25 & $100 \%$ \\
\hline 2 & $\begin{array}{l}\text { The human resources policies and } \\
\text { practices relevant to the program are } \\
\text { developed and undertaken in } \\
\text { consultation with employees, trade } \\
\text { unions or other employee } \\
\text { representative bodies as appropriate }\end{array}$ & 6 & $26 \%$ & 0 & $0 \%$ \\
\hline
\end{tabular}


Nina Karina K., Animah, \& Elin Erlina S., : Pengungkapan Anti Korupsi ...

The company makes it clear that no employee will suffer demotion, penalty or other adverse consequences for refusing to pay

1 bribes even if such refusal may result in the enterprise losing the business Reports the percentages of

4 employees trained in the organization's anti-corruption policies and procedures

Sumber: Data diolah

\subsubsection{Pengungkapan Hubungan Bisnis Yang Bertanggungjawab}

Tabel 4.4. menyajikan pengungkapan mengenai hubungan bisnis yang bertanggungjawab. Pada Tabel 4.4 dapat dilihat bahwa perusahaan Malaysia lebih banyak mengungkapkan semua item daripada perusahaan Indonesia terutama untuk item nomor 1 hingga nomor 8 . Selain itu, dapat dilihat bahwa baik dari perusahaan Malaysia maupun perusahaan Indonesia sama sekali tidak mengungkapkan item nomor 9 yaitu pengungkapan mengenai kontrak yang dihentikan. 
Tabel 4.4. Pengungkapan Hubungan Bisnis yang Bertanggung Jawab

\begin{tabular}{|c|c|c|c|c|c|}
\hline \multirow[t]{2}{*}{ No } & \multirow[t]{2}{*}{ Item Pengungkapan } & \multicolumn{2}{|c|}{ Indonesia $(n=23)$} & \multicolumn{2}{|c|}{ Malaysia $(n=25)$} \\
\hline & & Total & $\%$ & Total & $\%$ \\
\hline 1 & $\begin{array}{l}\text { The company monitors the } \\
\text { programs and performances of } \\
\text { joint ventures and consortia; in the } \\
\text { case of policies and practices that } \\
\text { are inconsistent with its own } \\
\text { program, the enterprises should } \\
\text { take appropriate action. This can } \\
\text { include: requiring corrections of } \\
\text { deficiencies in the implementation } \\
\text { of the program, application of } \\
\text { sanctions, or termination of its } \\
\text { participation in the joint venture or } \\
\text { consortium }\end{array}$ & 9 & $39 \%$ & 19 & $76 \%$ \\
\hline 2 & $\begin{array}{l}\text { Where the company is unable to } \\
\text { ensure that a joint venture or } \\
\text { consortium has a program } \\
\text { consistent with its own, it should } \\
\text { have a plan to exit from the } \\
\text { arrangement if bribery occurs or is } \\
\text { reasonably thought to have } \\
\text { occurred }\end{array}$ & 3 & $13 \%$ & 8 & $32 \%$ \\
\hline 3 & $\begin{array}{l}\text { The company ensures that } \\
\text { remuneration of agents is } \\
\text { appropriate and for legitimate } \\
\text { services only. Where relevant, a } \\
\text { list of agents employed in } \\
\text { connection with transactions with } \\
\text { public bodies and state-owned } \\
\text { enterprises should be kept and } \\
\text { made available to competent } \\
\text { authorities }\end{array}$ & 10 & $43 \%$ & 11 & $44 \%$ \\
\hline 4 & $\begin{array}{l}\text { The company contractually } \\
\text { requires its agents and other } \\
\text { intermediaries to keep proper } \\
\text { books and records available for } \\
\text { inspections by the enterprise, } \\
\text { auditors or investigating } \\
\text { authorities }\end{array}$ & 3 & $13 \%$ & 7 & $28 \%$ \\
\hline 5 & $\begin{array}{l}\text { The company monitors the conduct } \\
\text { of its agents and other } \\
\text { intermediaries and should have a } \\
\text { right of termination in the event } \\
\text { that they bribe or act in a manner } \\
\text { inconsistent with the enterprise's } \\
\text { program }\end{array}$ & 3 & $13 \%$ & 7 & $28 \%$ \\
\hline 6 & $\begin{array}{l}\text { The company conducts its } \\
\text { procurement practices in a fair and } \\
\text { transparent manner }\end{array}$ & 15 & $65 \%$ & 21 & $84 \%$ \\
\hline
\end{tabular}


Nina Karina K., Animah, \& Elin Erlina S., : Pengungkapan Anti Korupsi ...

The company makes known its

7 anti-corruption policies to

16

$70 \% \quad 21$

$84 \%$

contractors and suppliers

The company monitors significant

contractors and suppliers as part of

its regular review of relationships

8

with them and has a right to

terminate in the event that they

3

$13 \% \quad 8 \quad 32 \%$

pay bribes or act in a manner

inconsistent with the enterprise's

program

9 The company reports the number of contracts terminated

Sumber: Data diolah

\subsubsection{Pengungkapan Verifikasi dan Jaminan Pihak Eksternal}

Tabel 4.5. menyajikan pengungkapan mengenai verifikasi dan jaminan pihak eksternal. Pada Tabel 4.5 dapat dilihat bahwa sedikit sekali perusahaan yang mengungkapkan hal ini. Sebagaimana dapat dilihat dalam Tabel 4.5, hanya ada 3 perusahaan Indonesia yang mengungkapkan item no 3 dan hanya 1 perusahaan Indonesia yang mengungkapkan item nomor 2 . Sedangkan tidak satupun perusahaan Malaysia yang mengungkapkan ketiga item dalam bagian ini.

Tabel 4.5. Verifikasi dan Jaminan Pihak Eksternal

\begin{tabular}{|c|c|c|c|c|c|}
\hline \multirow[t]{2}{*}{ No } & \multirow[t]{2}{*}{ Item Pengungkapan } & \multicolumn{2}{|c|}{ Indonesia $(n=23)$} & \multicolumn{2}{|c|}{ Malaysia $(n=25)$} \\
\hline & & Total & $\%$ & Total & $\%$ \\
\hline 1 & $\begin{array}{l}\text { The board or equivalent body } \\
\text { should consider whether to } \\
\text { commission external verification or } \\
\text { assurance of anticorruption policies } \\
\text { and systems to provide enhanced } \\
\text { internal and external assurance of } \\
\text { the program's effectiveness }\end{array}$ & 3 & $13 \%$ & 0 & $0 \%$ \\
\hline 2 & $\begin{array}{l}\text { Where such external verification or } \\
\text { assurance is conducted, the board } \\
\text { or equivalent body should consider } \\
\text { publicly disclosing that an external } \\
\text { review has taken place, together } \\
\text { with the related verification or } \\
\text { assurance opinion }\end{array}$ & 1 & $4 \%$ & 0 & $0 \%$ \\
\hline 3 & $\begin{array}{l}\text { Assurance statements explicitly } \\
\text { cover program reporting }\end{array}$ & 0 & $0 \%$ & 0 & $0 \%$ \\
\hline
\end{tabular}

Sumber: Data diolah 


\subsubsection{Pengungkapan Kode Etik}

Tabel 4.6. Pengungkapan Kode Etik

\begin{tabular}{|c|c|c|c|c|c|}
\hline \multirow[t]{2}{*}{ No } & \multirow[t]{2}{*}{ Item Pengungkapan } & \multicolumn{2}{|c|}{ Indonesia $(n=23)$} & \multicolumn{2}{|c|}{ Malaysia $(n=25)$} \\
\hline & & Total & $\%$ & Total & $\%$ \\
\hline 1 & $\begin{array}{l}\text { Establishment of Codes of Conduct } \\
\text { relates to corruption practices }\end{array}$ & 23 & $100 \%$ & 25 & $100 \%$ \\
\hline 2 & $\begin{array}{l}\text { The Code of Conduct is effectively } \\
\text { communicated to the members of } \\
\text { the organization }\end{array}$ & 23 & $100 \%$ & 25 & $100 \%$ \\
\hline 3 & $\begin{array}{l}\text { Establishment of a monitoring } \\
\text { mechanism on the implementation } \\
\text { of the Codes of Conduct }\end{array}$ & 21 & $91 \%$ & 25 & $100 \%$ \\
\hline
\end{tabular}

Sumber: Data diolah

Tabel 4.6. menyajikan pengungkapan mengenai kode etik. Pada Tabel 4.6 dapat dilihat bahwa semua perusahaan baik dari Malaysia maupun Indonesia mengungkapkan item nomor 1 dan 2 dari 3 item yang ada pada bagian ini. Selain itu dapat dilihat bahwa perusahaan Malaysia lebih banyak mengungkapkan item ketiga daripada perusahaan Indonesia. Namun secara umum dapat dilihat bahwa hampir sebagian besar perusahaan Indonesia dan Malaysia mengungkapkan ketiga item dalam bagian ini.

\subsubsection{Pengungkapan Kebijakan Whistle Blowing}

Tabel 4.6. Pengungkapan Kebijakan Whistleblowing

\begin{tabular}{|c|c|c|c|c|c|}
\hline \multirow[t]{2}{*}{ No } & \multirow[t]{2}{*}{ Item Pengungkapan } & \multicolumn{2}{|c|}{ Indonesia $(n=23)$} & \multicolumn{2}{|c|}{ Malaysia $(n=25)$} \\
\hline & & Total & $\%$ & Total & $\%$ \\
\hline 1 & $\begin{array}{l}\text { Existence of a whistle-blowing } \\
\text { policy }\end{array}$ & 23 & $100 \%$ & 25 & $100 \%$ \\
\hline 2 & $\begin{array}{l}\text { Implementation of whistle-blowing } \\
\text { practices }\end{array}$ & 23 & $100 \%$ & 25 & $100 \%$ \\
\hline
\end{tabular}

Sumber: Data diolah

Tabel 4.7. menyajikan pengungkapan mengenai kebijakan whistle blowing. Pada Tabel 4.7 dapat dilihat bahwa semua perusahaan baik dari Malaysia maupun Indonesia mengungkapkan semua item pada bagian ini. Dari keseluruhan tema umum, hanya bagian inilah yang diungkapkan penuh oleh semua perusahaan dalam sampel penelitian ini.

\subsection{Hasil Uji Hipotesis}

Pada bagian ini akan disajikan mengenai hasil uji hipotesis mengenai hubungan antara pengungkapan anti korupsi dengan kinerja keuangan perusahaan baik kinerja keuangan jangka pendek maupun jangka panjang. Hubungan antara pengungkapan anti korupsi dan kinerja keuangan perusahaan baik jangka pendek maupun jangka panjang dianalisis dengan menggunakan uji regresi linear berganda. Hasil uji hipotesis ini disajikan pada Tabel 4.8 dan Tabel 4.9 berikut.

Tabel 4.8. Hasil Uji Hipotesis Sampel Perusahaan Indeks Sri Kehati Indonesia 
Nina Karina K., Animah, \& Elin Erlina S., : Pengungkapan Anti Korupsi ...

\begin{tabular}{lcccc} 
& \multicolumn{2}{c}{ ROA } & \multicolumn{2}{c}{ TOBIN'S Q } \\
\cline { 2 - 5 } & B & Sig & B & Sig \\
\hline Konstanta & 0.417 & & 9.829 \\
ACDI & 0.063 & 0.752 & 16.624 & 0.028 \\
SIZE & -0.012 & 0.551 & -0.478 & 0.499 \\
LEV & -0.002 & 0.912 & -0.619 & 0.290 \\
F (sig) & \multicolumn{2}{c}{0.840} & \multicolumn{2}{c}{0.060} \\
ADJ R R & \multicolumn{2}{c}{0.109} & \multicolumn{2}{c}{0.208} \\
\hline
\end{tabular}

Sumber: Data diolah

Tabel 4.8 menunjukkan hasil regresi untuk sampel penelitian perusahaan yang terdaftar di Indeks Sri Kehati Indonesia. Hasil uji regresi menunjukkan bahwa pada tingkat signifikansi 0,05 , pengungkapan anti korupsi (ACDI) tidak memiliki pengaruh yang signifikan terhadap ROA pada tingkat signifikansi 0,05 . Nilai $A d j$. $R^{2}$ sebesar $-0,02$ menunjukkan bahwa variabel independen hanya menjelaskan sebagian kecil dari variasi ROA. Hal ini menunjukkan bahwa perhatian perusahaan untuk isu anti korupsi tidak mempengaruhi profitabilitas jangka pendek. Sebagaimana yang ditunjukkan oleh Tabel 4.8, hasil penelitian juga menunjukkan bahwa pengungkapan anti korupsi (ACDI) memiliki pengaruh yang signifikan terhadap Tobin's Q pada tingkat signifikansi 0,05. Nilai Adj. $\mathrm{R}^{2}$ sebesar 0,208 menunjukkan bahwa variabel independen menjelaskan $28 \%$ dari variasi Tobin's Q. Hasil uji regresi juga menunjukkan bahwa variabel pengungkapan anti korupsi memiliki arah hubungan yang positif terhadap Tobin Q. Jadi hal ini menunjukkan bahwa perhatian perusahaan untuk mengungkapkan anti korupsi dapat meningkatkan profitabilitas perusahaan di masa depan.

Tabel 4.9. Hasil Uji Hipotesis Sampel Perusahaan Indeks FTSEGoods Malaysia

\begin{tabular}{lcccc}
\hline & \multicolumn{2}{c}{ ROA } & \multicolumn{2}{c}{ TOBIN'S Q } \\
\cline { 2 - 5 } & \multicolumn{1}{c}{$\beta$} & Sig & B & Sig \\
\hline Konstanta & 0.872 & \multicolumn{3}{c}{21.984} \\
ACDI & 0.402 & 0.013 & 7.547 & 0.026 \\
SIZE & -0.047 & 0.001 & -1.121 & 0.000 \\
LEV & 0.027 & 0.002 & 0.554 & 0.002 \\
F (sig) & \multicolumn{2}{c}{0.006} & \multicolumn{2}{c}{0.003} \\
ADJ R R & \multicolumn{2}{c}{0.397} \\
\hline
\end{tabular}

Sumber: Data diolah

Tabel 4.9 menunjukkan hasil regresi untuk sampel penelitian perusahaan yang terdaftar di Indeks FTSEGoods Malaysia. Hasil uji regresi menunjukkan bahwa pengungkapan anti korupsi (ACDI) memiliki pengaruh yang signifikan terhadap ROA pada tingkat signifikansi 0,05 . Nilai Adj. $R^{2}$ sebesar 0.357 menunjukkan bahwa variabel independen dapat menjelaskan $35,7 \%$ dari variasi ROA. Selain itu, arah yang positif menunjukkan bahwa perhatian perusahaan untuk isu anti korupsi meningkatkan profitabilitas 
jangka pendek. Sebagaimana yang ditunjukkan oleh Tabel 4.9, hasil penelitian juga menunjukkan bahwa pada tingkat signifikansi 0,05, pengungkapan anti korupsi (ACDI) memiliki pengaruh yang signifikan terhadap Tobin's Q. Nilai Adj. $R^{2}$ sebesar 0,397 menunjukkan bahwa variabel independen menjelaskan 39.7\% dari variasi Tobin's Q. Hasil uji regresi juga menunjukkan bahwa variabel pengungkapan anti korupsi memiliki arah hubungan yang positif terhadap Tobin Q. Jadi hal ini menunjukkan bahwa perhatian perusahaan untuk mengungkapkan anti korupsi juga dapat meningkatkan profitabilitas perusahaan di masa depan.

\subsection{Interpretasi Hasil Penelitian}

Tujuan utama dari penelitian ini adalah untuk menguji pengaruh pengungkapan anti korupsi terhadap profitabilitas perusahaan dalam jangka pendek dan evaluasi pasar terhadap profitabilitas perusahaan masa depan pada perusahaan-perusahaan yang terdaftar di Indeks Sri Kehati Indonesia dan Indeks FTSEGoods Malaysia. Seperti ditunjukkan pada Tabel 4.8 pengungkapan anti korupsi hanya berpengaruh signifikan terhadap profitabilitas perusahaan dalam jangka panjang untuk perusahaan yang terdaftar di Indeks Sri Kehati Indonesia. Walaupun hasil penelitian menunjukkan pengungkapan anti korupsi tidak berpengaruh signifikan terhadap profitabilitas perusahaan dalam jangka panjang, hasil uji regresi menunjukkan arah yang positif bagi kedua hasil uji regresi baik dengan ROA yang menunjukkan kinerja keuangan jangka pendek maupun dengan Tobin's Q yang menunjukkan kinerja keuangan jangka panjang. Sedangkan bagi sampel perusahaan yang terdaftar di Indeks FTSEGoods Malaysia, hasil penelitian menunjukkan bahwa pengungkapan anti korupsi berpengaruh terhadap kinerja keuangan perusahaan baik dalam jangka pendek maupun dalam jangka panjang. Hasil uji regresi juga menunjukkan arah yang positif bagi kedua hasil uji regresi baik dengan ROA yang menunjukkan kinerja keuangan jangka pendek maupun dengan Tobin's $Q$ yang menunjukkan kinerja keuangan jangka panjang.

Secara umum, temuan ini menunjukkan bahwa perhatian perusahaan terhadap anti korupsi mempengaruhi produktivitas atau evaluasi pasar perusahaan baik yang terdaftar di Indeks Sri Kehati Indonesia dan Indeks FTSEGoods Malaysia. Perusahaan yang terdaftar pada indeks ini dianggap memiliki bermacam bentuk pertimbangan dalam usahanya berkaitan dengan kepedulian pada lingkungan, tata kelola perusahaan, keterlibatan masyarakat, sumber daya manusia, hak asasi manusia, dan perilaku bisnis dengan etika bisnis yang diterima di tingkat international. Untuk mempertahankan posisi mereka dalam indeks tersebut, perusahaan akan cenderung melakukan aktivitas CSR, dalam hal ini pengungkapan anti korupsi untuk menciptakan dan menjaga citra positif untuk mempengaruhi nilai perusahaan. Pengungkapan anti korupsi sebagai bagian dari pengungkapan CSR mengirimkan sinyal yang menyatakan bahwa perusahaan peduli dengan pencegahan korupsi yang dapat mengancam keberlangsungan hidup perusahaan dan masyarakat pada umumnya. Hal ini direspon oleh investor yang terlihat dari pengaruh signifikan pengungkapan anti korupsi terhadap kinerja keuangan jangka panjang bagi Indonesia dan kinerja keuangan jangka pendek maupun kinerja keuangan jangka panjang bagi perusahaan Malaysia.

Hasil penelitian ini mendukung Teori Legitimasi yang menyatakan bahwa pengungkapan informasi digunakan sebagai alat bagi organisasi untuk mencitrakan dirinya sebagai organisasi yang penuh tanggung jawab dan 
Nina Karina K., Animah, \& Elin Erlina S., : Pengungkapan Anti Korupsi ...

beroperasi sesuai dengan nilai-nilai sosial agar dapat mempertahankan atau memperoleh legitimasi sosial (Cuganesan, Ward \& Guthrie, 2007). Legitimasi dianggap penting bagi perusahaan karena legitimasi masyarakat terhadap perusahaan merupakan faktor yang strategis bagi perkembangan perusahaan di masa depan. Untuk itu sebagai suatu sistem yang mengutamakan masyarakat, aktivitas operasional perusahaan juga harus sesuai dengan harapan masyarakat karena kelangsungan hidup dan perumbuhan perusahaan bergantung pada bagaimana perusahaan secara terus menerus berevolusi dan beradaptasi dengan perubahan tuntutan masyarakat (Walden \& Schwartz, 1997).

\section{Penutup}

\subsection{Simpulan}

Tujuan utama dari penelitian ini adalah untuk menguji pengaruh pengungkapan anti korupsi terhadap profitabilitas perusahaan dalam jangka pendek dan evaluasi pasar terhadap profitabilitas perusahaan masa depan pada perusahaan-perusahaan yang terdaftar di Indeks Sri Kehati Indonesia dan Indeks FTSEGoods Malaysia. Pengungkapan anti korupsi diukur berdasarkan Indeks anti korupsi yang terdiri dari 7 tema umum dengan 40 sub kategori. Tema umum tersebut adalah 1 ) pengungkapan akuntansi untuk melawan korupsi/suap 2) tanggung jawab dewan dan manajemen senior 3) pembinaan sumber daya manusia untuk melawan korupsi/suap 4) hubungan bisnis yang bertanggungjawab 5) verifikasi dan jaminan pihak eksternal 6) kode etik 7) kebijakan whistle blowing. Hasil penelitian menunjukkan bahwa dari keseluruhan tema umum pengungkapan anti korupsi, hanya bagian mengenai kebijakan whistleblowing saja yang diungkapkan penuh oleh semua perusahaan dalam sampel penelitian ini. Hasil penelitian juga menunjukkan bahwa pengungkapan anti korupsi hanya berpengaruh signifikan terhadap profitabilitas perusahaan dalam jangka panjang untuk perusahaan yang terdaftar di Indeks Sri Kehati Indonesia. Sedangkan bagi sampel perusahaan yang terdaftar di Indeks FTSEGoods Malaysia, hasil penelitian menunjukkan bahwa pengungkapan anti korupsi berpengaruh terhadap kinerja keuangan perusahaan baik dalam jangka pendek maupun dalam jangka panjang. Selain itu, hasil penelitian menunjukkan arah yang positif bagi semua hasil uji regresi yang berarti mendukung hipotesis penelitian dan teori yang mendasari penelitian ini. 


\subsection{Keterbatasan Penelitian}

Hasil penelitian ini yang menunjukkan bahwa pengungkapan anti korupsi berpengaruh positif terhadap kinerja keuangan perusahaan. Namun, prinsip kehati-hatian harus diterapkan dalam menginterpretasikan hasil dari penelitian ini karena penelitian hanya difokuskan pada indeks tertentu sehingga hasil penelitian kemungkinan dapat berbeda dengan karakteristik perusahaan yang berbeda. Selain itu penelitian ini hanya menggunakan data untuk tahun 2015 saja untuk masing-masing model penelitian yang diujikan. Hal ini mengakibatkan ukuran sampel yang relatif kecil. Replikasi dari penelitian ini dapat dilakukan jika ukuran sampel yang lebih besar tersedia di masa depan, sehingga dapat memberikan temuan yang lebih kuat atau hasil yang berbeda. Penelitian ini juga menggunakan analisa konten untuk menghitung luas pengungkapan anti korupsi yang dilaporkan perusahaan. Analisis konten memiliki kelemahan karena sangat dipengaruhi oleh subjektifitas peneliti dalam menginterpretasikan pengungkapan anti korupsi.

\subsection{Saran}

Dengan mempertimbangkan keterbatasan penelitian di atas, sebagai saran untuk penelitian selanjutnya agar bisa memperoleh gambaran yang lebih baik dalam melihat pengaruh multidimensionalitas tanggung jawab sosial perusahaan jasa terhadap kinerja keuangan antara lain:

1. Menambah jumlah sampel bila memungkinkan

2. Menggunakan ukuran kinerja keuangan lain seperti ROE dan EVA

3. Meneliti perusahaan dari sektor lain seperti ritel dan perdagangan

\section{Daftar Pustaka}

ACCA, 2008. Reporting Trilogy e Research on Reporting Disclosures Part 1: Anticorruption and Corruption Reporting Disclosures.

Akhtaruddin, M, Hossain, MA, Hossain, M \& Yao, L 2009, 'Corporate governance and voluntary disclosure in corporate annual reports of Malaysian listed firms', Journal of Applied Management Accounting, vol. 7, no. 1, pp. 1-17.

Arafa, Mohameed A. Battling Corruption within a Corporate Social Responsibility Strategy. Indiana International \& Comparative Law Review, Vol. 21, No. 3, 2011. Available in http://papers.ssrn.com/sol3/papers.cfm? abstract_id=1933629

Bierstaker, J.L., 2009. Differences in attitudes about fraud and corruption across cultures: theory, examples and recommendation. Cross Cult. Manag. Int. J. 16, 241e260.

Chapple, W., Moon, J., 2005. Corporate Social Responsibility (CSR) in Asia: a sevencountryvstudy of CSR Website reporting. Bus. Soc. 44, 415e441.

Chen, JC \& Roberts, RW 2010, 'Toward a more coherent understanding of the organization-society relationship: A theoretical consideration for social and environmental accounting research', Journal of Business Ethics, vol. 97 , no. 4 , pp. 651-665.

Cochran, P. L., \& Wood, R. A. 1984. Corporate social responsibility and financial performance. Academy of Management Journal, 27, 42-56 
Nina Karina K., Animah, \& Elin Erlina S., : Pengungkapan Anti Korupsi ...

Coonjohn, J.J., Lodin, A., 2011. Developing a Strategic Implementation Plan for Anticorruption. Retrieved from: http://www.jjcoonjohn.com/pdf/ Strategic_Implementation_Plan.pdf

Cuganesan, S., Ward, L. \& Guthrie, J. 2007. Legitimacy theory: a story of reporting social and environmental matters within the Australian food and beverage industry. Dipresentasikan pada 5th Asian Pacific Interdisciplinary Research in Accounting (APIRA) Conference, 8-10 Juli 2007, Auckland, New Zealand. Diakses 3 Maret 2012 dari: http://ssrn.com/abstract $=1360518$

Dahlia, Lely dan Sylvia Veronica Siregar. 2008. Pengaruh Corporate Social Responsibility terhadap Kinerja Perusahaan. Simposium Nasional Akuntansi 11, Pontianak

Dissanayake, T., Islam, M.A., Dellaportas, S., 2011. In: Corporate Disclosure on Combatting Bribery: a Study of Two Global Companies in the Telecommunication Industry Paper Presented at the 10th Australasian Conference on Social and Environmental Accounting Research (CSEAR), 5e7 December. University of Tasmania, Australia.

Doh, J., Rodriguez, P., Uhlenbruck, K., Collins, J. and Eden, L. (2003) 'Coping with Corruption in Foreign Markets', Academy of Management Executive 17 (3): 114-127.

Elkington, J. 2005. Cannibals with forks, the triple bottom line of twentieth century business. Dikutip dari Teguh Sri Pembudi. CSR. Sebuah Keharusan dalam Investasi Sosial. Pusat Penyuluhan Sosial (PUSENSOS) Departemen Sosial RI. Jakarta. La Tofi Enterprise.

Gray, R, Kouhy R \& Lavers, S. 1995. Corporate social and environmental reporting: A review of the literature and a longitudinal study of UK disclosure. Accounting, Auditing \& Accountability Journal, vol. 8, no. 2, pp. 47-77.

Gray, R, Owen, D \& Adams, C .1996. Accounting and accountability: Changes and challenges in corporate social and environmental reporting. Prentice Hall, London.

Gunawan, J., 2007. Corporate social disclosures by Indonesian listed companies: a pilot study. Soc. Responsib. J. 3, $26 \mathrm{e} 34$.

Guthrie, J, Petty, R. and Yongvanich, K. 2004 'Using content analysis as a research method to inquire into intellectual capital reporting', Journal of Intellectual Capital, 5(2):282-293

Haniffa, RM \& Cooke, TE 2002, 'Culture, corporate governance and disclosure in Malaysian corporations', ABACUS, vol. 38, no. 3, pp. 317-349.

Heal, Geoffrey, dan Garret, Paul. 2004. Corporate Social Responsibility, An Economic and Financial Framework. Columbia Business School.

Healy, P., Serafeim, G., 2011. Causes and Consequences of Firms Disclosures of Anti-corruption Efforts. Working Paper. Harvard Business School.

Healy, P., Serafeim, G., 2014. An Analysis of Firms' Self-reported Anticorruption Efforts. Working Paper. Harvard Business School.

Hess, D., 2009. Catalyzing corporate commitment to combatting corruption. J. Bus. Ethics 88, 781e790.

Hills, G., Fisk, L., Mahmud, A., 2009. Anti-corruption as Strategic CSR: a Call toAction for Corporations. Retrieved from: www.ethics.org/files/u5/ AnticorruptionFINAL.pdf.

Hillman, A. J., \& Keim, G. D. 2001. Shareholder value, stakeholder management,and social issues: what's the bottom line? Strategic Management Journal, 22, 125-139. 
Hoi, Y.H., Lin, C.Y., 2012. Preventing corporate corruption: the role of corporate social responsibility strategy. Int. J. Bus. Behav. Sci. 2, $12 \mathrm{e} 22$.

Hull, C. E., \& Rothenberg, S. 2008. Firm performance: the interactions of corporate social performance with innovation and industry differentiation. Strategic Management Journal, 29, 781-789.

Indriantoro, Nur. 2002. Metodologi Penelitian Bisnis untuk Akuntansi dan Manajemen. Cetakan 2. BPFE-Yogyakarta. Yogyakarta

Islam, M. \& Deegan, C., (2008), 'Motivations for an organisation within a developing country to report social responsibility information: Evidence from Bangladesh', Accounting Auditing \& Accountability Journal, Vol. 21, No. 6, pp. 850-874.

Islam, M. \& Deegan, C., (2010), 'Media Pressures and Corporate Disclosure of Social Responsibility Performance: A Case Study of Two Global Clothing and Sports Retail Companies', Accounting and Business Research J ournal, Vol 40, No.2. pp.131-148.

Jensen, M. C., \& Meckling, W. H. 1976. "Theory of The Firm: Managerial Behavior, Agency Costs and Ownership Structure". Journal of Financial Economic. 3, 305--360.

Joseph, C., Gunawan, J., Sawani, Y., Rahmat, M., Noyem, J.A., Darus, F. 2015. A comparative study of anti-corruption practice disclosure among Malaysian and Indomesian Corporate Social Responsibility (CSR) best practice companies. Journal of Cleaner Production xxx 111.

Kang, K. H., Lee, S., \& Huh, C. 2010. Impacts of positive and negative corporate social responsibility activities on company performance in the tourism industry. International Journal of Hospitality Management, 29(1), 72-82.

KPMG, 2008. KPMG International Survey on Corporate Responsibility Reporting.

Lange, D. A. (2008). A multidimensional conceptualization of organizational corruption control. Academy of Management Review, 33: 710-729.

Luo, X., \& Bhattacharya, C. B. 2006. Corporate social responsibility, customer satisfaction, and market value. Journal of Marketing, 70, 1-18.

McWilliams, A., \& Siegel, D. 2000. Corporate social responsibility and financial performance: correlation or misspecification? Strategic Management Journal, 21(5), 603-609.

National Geographic, 2015. Asia: Resources Environment and Economy. Retrieved from: http://education.nationalgeographic.com/education/ encyclopedia/asiaresources/?ar_a $1 / 41$.

O'Higgins, E. (2006). Corruption, underdevelopment, and extractive resource industries: Addressing the vicious cycle. Business Ethics Quarterly, 16: 235-254.

OTSI, 2010. Fraud and Corruption Prevention Strategy. The Office of Transport Safety. Retrieved from: www.otsi.nsw.gov.au/access-toinfo/OTSI-Fraud- Strategy.pdf.

Osuji, O. (2011). Fluidity of regulation-CSR nexus: the multinational corporate corruption example. J ournal of Business Ethics, 103: 31-57.

Political \& Economic Risk Consultancy Ltd, 2011. S.W.O.T. Study of Asia's Emerging Countries. Retrieved from http://www.asiarisk.com/ library2.pdf. 
Nina Karina K., Animah, \& Elin Erlina S., : Pengungkapan Anti Korupsi ...

Roberts, R.W.: 1992, 'Determinants of Corporate Social Responsibility Disclosure: AnApplication of Stakeholder Theory', Accounting, Organizations and Society 17(6), 595-612.

Sayekti, Y., \& Wondabio, L. S. (2007). Pengaruh CSR Disclosure terhadap Earning Response Coefficient. Paper presented at the Simposium Nasional Akuntansi X.

Solimun, 2007, Memahami Metode Kuantitatif Mutakhir Structural Equation Modeling \& Partial Least Square. Program Studi Statistika FMIPA Universitas Brawijaya Malang.

Transparency International, 2009a. Transparency in Reporting on Anticorruption. A Report on Corporate Practices, Berlin.

Transparency International, 2010. Corporate Responsibility \& Anti-corruption: the Missing Link, Working Paper. Retrieved from: www.transparency.org

Transparency International, 2014. Corruption Index Improve but Still Not Encouraging. Retrieved from: http://www.dw.de/indeks-korupsiperingkat-indonesiamembaik-tapi-masihburuk/a18107694.

Transparency International, 2015. Archive Link. Retrieved from: http://archive.transparency.org/news room/faq/corruption faq.

Ullmann, A.A.: 1985, 'Data in Search of a Theory: A Critical Examination of the Relationshipsamong Social Performance, Social Disclosure, and Economic Performance of U.S. Firms', The Academy of Management Review 10(3), 540-557.

van Dijken, Francisca, .2007. Corporate social responsibility: market regulation and the evidence. Managerial Law, Vol. 49 Iss: 4, pp.141 184

Walden, W.D. and Schwartz, B.N. 1997, "Environmental disclosures and public policy pressure", J ournal of Accounting and Public Policy, Vol. 16 No. 2, pp. $125-54$.

Weyzig, F., 2009. Political and economic arguments for corporate social responsibility: analysis and a proposition regarding the CSR Agenda. J. Bus. Ethics 86, 417 e428.

www.globalreporting.org

Undang-Undang Republik Indonesia No. 40 Tahun 2007 tentang Perseroan Terbatas. Retrieved February 28, 2008, from http://bapepam.go.id/reksadana/files/regulasi/UU\%2040\%202007\%2 OPerseroan\%20Terbatas.pdf 